\title{
Stable isotope compositions and trace element concentrations in freshwater bivalve shells (Unio sp.) as indicators of environmental changes at Tiszapüspöki, eastern Hungary
}

\author{
Attila Demény, Gabriella Schöll-Barna \\ István Fórizs \\ Institute for Geological and Geochemical Research \\ Research Centre for Astronomy and Earth Sciences \\ Hungarian Academy of Sciences, Budapest
}

\author{
János Osán \\ Centre for Energy Research, \\ Hungarian Academy of Sciences, Budapest
}

\section{Pál Sümegi}

Department of Geology and Paleontology

University of Szeged, Szeged
Bernadett Bajnóczi

Institute for Geological and Geochemical Research Research Centre for Astronomy and Earth Sciences Hungarian Academy of Sciences, Budapest

Stable carbon and oxygen isotope compositions of living Unio shells and oxygen isotope compositions of water samples were determined in order to demonstrate how the shells' compositions can reflect environmental conditions. With this information in hand, fossil shell fragments from a sedimentary section at Tiszapüspöki covering the period of about 3.5 to $10 \mathrm{ky}$ BP were analyzed for their stable isotope as well as trace element compositions. Beside the determination of sedimentary facies effects on the geochemical compositions, the combined evaluation of isotopic and trace element records allowed us to detect past environmental changes at a millennial scale. The data indicate that the period of 6 to $8 \mathrm{ky} \mathrm{BP}$ was characterized by humid summers that - on the basis of comparison with an Alpine speleothem record - was associated with a generally warmer climate and increased winter precipitation in the Alps.

Key words: Unio shells, stable isotope geochemistry, Holocene, Tisza river, paleoclimate

\section{Introduction}

Stable isotope studies on freshwater bivalve shells in paleoclimate research have gained importance in recent decades (e.g. Dettman and Lohmann 1993; AlAasm et al. 1998; Tevesz et al. 1998; Davis and Muehlenbachs 2001; Wurster and Patterson 2001; Verdegaal et al. 2005; Baroni et al. 2006; Apolinarska 2009a,b; Bucci et al. 2009; Versteegh et al. 2009; 2010a, b; 2011; Bar-Yosef Mayer et al. 2012). Stable

\footnotetext{
Addresses: A. Demény, G. Schöll-Barna, I. Fórizs, B. Bajnóczi: H-1112 Budapest, Budaörsi út 45, Hungary, e-mails: demeny.attila@csfk.mta.hu; barnagabriella@gmail.com; forizs.istvan@csfk.mta.hu; bajnoczi.bernadett@csfk.mta.hu

J. Osán: H-1525 Budapest, P.O. Box 49, Hungary: e-mail: osan.janos@energia.mta.hu P. Sümegi: H-6722 Szeged, Egyetem u. 2, Hungary, e-mail: sumegi@geo.u-szeged.hu Received: February 19, 2013; accepted: June 10, 2013
} 
carbon and oxygen isotope compositions have been shown to reflect temperature and humidity variations in a lacustrine environment and were successfully used to detect past climate variations from about $5 \mathrm{ky}$ ago in the area of Lake Balaton, Hungary (Schöll-Barna et al. 2012). The use of freshwater mussel shells in paleoclimate studies has several advantages. The preservation of the original carbonate of aragonitic shells such as Unio species can easily be checked by cathodoluminescence (CL) microscopic analysis, as aragonite and calcite have distinctly different (green and orange, respectively) CL colors (Barbin 2000). The shells' lifetime reaches $4-5$ years, with sizes up to $10 \mathrm{~cm}$; hence simple drilling with a dental drill would allow a sampling resolution representing some weeks of growth. On the other hand, long-term (centennial or millennial) climate change processes can be investigated using average shell data from sedimentary sections that may cover thousands of years.

Beside stable $\mathrm{C}$ and $\mathrm{O}$ isotope compositions, trace element concentrations in the shells may also carry environmental information (Vander Putten et al. 2000; Lazareth et al. 2003; Anadón et al. 2008; Carroll and Romanek 2008; Carroll et al. 2009; Higuera-Ruiz and Elorza 2009). Although the shell-water partition coefficients depend on many factors such as temperature, metabolism, or growth rate, and incorporation of trace elements into the shell carbonate is a very complex process (Al-Aasm et al. 1998; Bailey and Lear 2006; Dick et al. 2007; Carroll and Romanek 2008; Cravo et al. 2008; Shirai et al. 2008; Foster et al. 2009), the relative changes among shells in a sedimentary sequence may point to changes in water composition. Arid climate would result in enhanced evaporation and - as a consequence - increased dissolved element concentration. More effective weathering and soil activity in the recharge area of the water can also increase certain elements sensitive to these processes, such as phosphorus.

The present study demonstrates how stable isotope compositions and trace element concentrations can be combined to investigate environmental changes in a fluvial environment in eastern Hungary. A sediment core of about $7 \mathrm{~m}$ was cut at Kartsú-ér, Tiszapüspöki. Shell fragments of Unio sp. were collected at a sampling resolution of $10-60 \mathrm{~cm}$ wherever the shells could be recovered. Additionally shells of live Unio specimens were collected from the Tisza river along with water samples to determine the degree to which the shells may reflect ambient conditions in this environment. Finally a preliminary comparison with regionally important paleoclimate records is presented that will serve as a basis for a further comprehensive study that would combine data from different deposits (such as speleothems) and biogenic fossils from lake sediments (see Demény et al. 2012 and Magyari et al. 2012 as examples).

\section{Location and samples}

Water samples from the Tisza river were collected at Szolnok (Fig. 1) during a three-year sampling campaign. Shells of live Unio specimens - altogether 23 of 

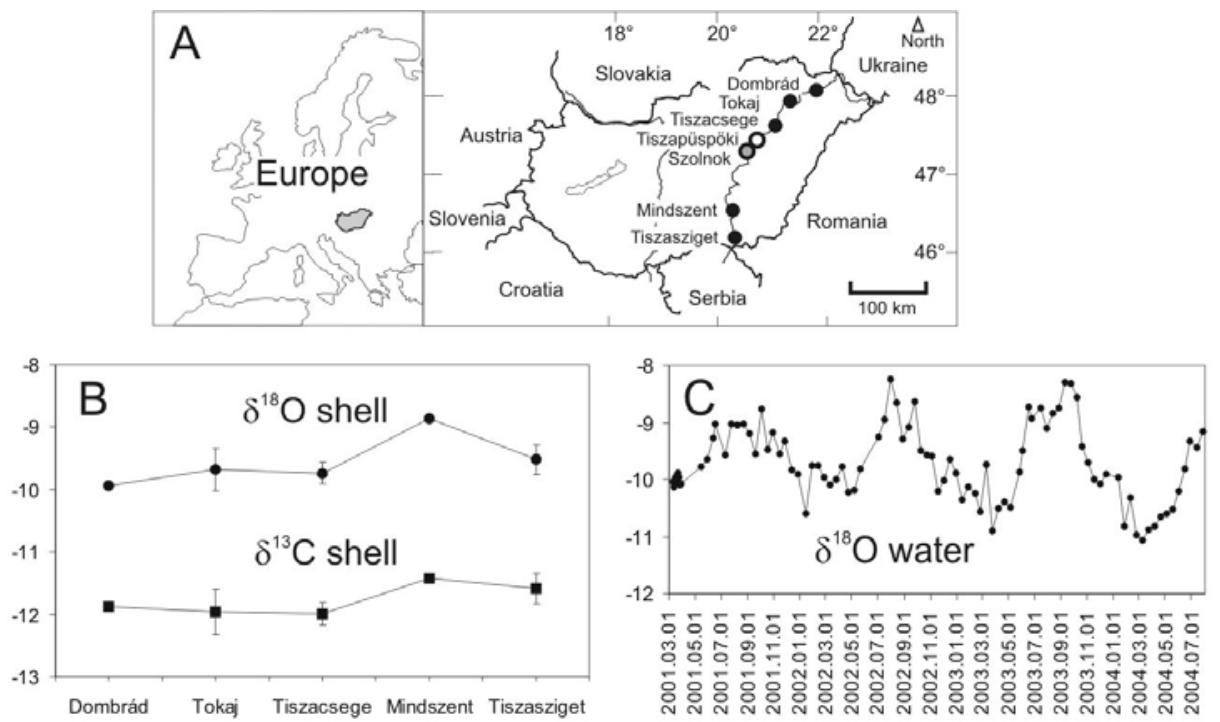

Fig. 1

A: Map of the sampling locations of Unio shells (living shells: black solid circles; fossil shell locality of Tiszapüspöki: empty circle) and water samples at Szolnok (grey filled circle). B and C: Stable carbon and oxygen isotope compositions (in \%o relative to V-PDB) of living shells collected at five locations along the Tisza river (A) and stable oxygen isotope compositions (in \%o relative to V-SMOW) of water samples collected at Szolnok

them - were collected at five locations along the river (Fig. 1) at the start of the water sampling campaign. The sediment section studied is situated in the Great Hungarian Plain at Tiszapüspöki, eastern Hungary. As described in Sümegi (2004), a $\sim 7 \mathrm{~m}$ deep core-hole was drilled into a fluvial sedimentary sequence, of which only the layers below $\sim 3 \mathrm{~m}$ could be studied due to anthropogenic disturbance. Based on conventional ${ }^{14} \mathrm{C}$ age dating (Sümegi 2004) the section covers the period of $\sim 9000$ to $\sim 3200$ years BP ("Before Present", i.e. before A.D. 1950), providing information on the development of the Early Holocene climate up to the so-called Holocene Climate Optimum ( $~ 8000$ to 5000 years BP), followed by the passage to present climate conditions. The core was obtained at the edge of the village of Tiszapüspöki in a formed drainage channel called Kartsú-ér. A detailed sedimentologic description is provided by Sümegi (2004). The section starts with a very finely-grained sand layer between 6.4 and $7.0 \mathrm{~m}$ with a significant amount of medium-sized sand fraction, indicating a high-energy fluvial environment. This assumption was supported by the presence of Unio crassus remnants that usually live in rapidly flowing water. Between 6.4 and $5.6 \mathrm{~m}$ depth the sandy sediment alternates with silt layers, indicating water level fluctuation in the river channel. At the depth of $5.6-5.4 \mathrm{~m}$ there is an organic-rich silty layer that was interpreted as a sign of increased soil erosion (Sümegi 2004). 
The fine-grained sand fraction decreases upsection from this layer with alternating sandy and silty layers $(5.4-4.0 \mathrm{~m})$, attributed to the formation of a periodically flooded plain and an oxbow lake (Sümegi 2004). At the depth of $4.0-3.8 \mathrm{~m}$ there is a coarser-grained sand layer representing the development of a river channel. Above $3.8 \mathrm{~m}$ the amount of organic matter and silt fraction increase, indicating eutrophization of the oxbow lake. Shell fragments, several $\mathrm{cm}$ in size, of the freshwater bivalve Unio sp. (a more precise determination was not possible due to the shells' fragmentation) were collected from the drill core.

\section{Analytical techniques}

Cathodoluminescence microscopic examination was performed using Reliotron "cold-cathode" equipment mounted on a Nikon Eclipse E600 microscope with a Nikon Coolpix 4500 digital camera and operated at 6 to $10 \mathrm{keV}$ acceleration voltage.

Shell samples were prepared and ${ }^{14} \mathrm{C}$-AMS analyzed in the Hertelendi Laboratory of MTA ATOMKI. Carbon dioxide was extracted from the samples using $85 \%$ phosphoric acid in a vacuum tight two-finger glass flask. The $\mathrm{CO}_{2}$ produced from the carbonate content of the sample was cleaned by a cryogenic gas purification system. The purified carbon dioxide was converted into AMS graphite target using the sealed tube graphitization method (Rinyu et al. 2013). The ${ }^{14} \mathrm{C}$ measurements were performed using the MICADAS type AMS at Hertelendi Lab, Debrecen (Synal et al. 2007; Molnár et al. 2012). Measurement time and conditions were set to collect at least 500,000 net counts for every single target. The overall measurement uncertainty for each sample is below 3\%o, including normalization, background subtraction and counting statistics.

Depending on shell size (from about 0.5 to about $1 \mathrm{~cm}$ ), three to eight subsamples from each shell fragment separated from the sediment core material were drilled equidistantly on outer surfaces as individual holes, using a $0.6 \mathrm{~mm}$ tip dental drill. Based on detailed studies of modern Unio shells from the Carpathian Basin (Schöll-Barna et al. 2012), these fragments may represent growth periods of about $0.5-1$ year. Modern shells were treated with sodium hypochlorite in order to remove the periostracum, the outer organic layer (Gaffey and Bronnimann 1993); the shells were then powdered and their bulk compositions measured. Stable carbon and oxygen isotope compositions of approximately 150-200 $\mu \mathrm{g}$ carbonate samples were determined applying the carbonate - orthophosphoric acid reaction at $72{ }^{\circ} \mathrm{C}$ (Spötl and Vennemann 2003) and using an automated GASBENCH II sample preparation device attached to a Thermo Finnigan Delta Plus XP mass spectrometer at the Institute for Geological and Geochemical Research, Budapest. Oxygen isotope compositions of water samples were determined by means of the conventional $\mathrm{CO}_{2}-\mathrm{H}_{2} \mathrm{O}$ equilibration method (Epstein and Mayeda 1953). One $\mathrm{ml}$ of water sample was equilibrated with $\mathrm{CO}_{2}$ at $32{ }^{\circ} \mathrm{C}$ for 18 hours, then the ${ }^{18} \mathrm{O} /{ }^{16} \mathrm{O}$ ratios were measured in the $\mathrm{CO}_{2}$ 
gas using the same automated GASBENCH II sample preparation device attached to a Thermo Finnigan Delta Plus XP mass spectrometer as for the carbonates. The isotope compositions of carbonate samples are expressed as $\delta^{13} \mathrm{C}$ and $\delta^{18} \mathrm{O}$ values relative to V-PDB, according to the equation: $\delta=\left(R_{\text {sample }} / R_{\text {standard }}-1\right) \cdot 1000$, where $\mathrm{R}$ is the ${ }^{13} \mathrm{C} /{ }^{12} \mathrm{C}$ or ${ }^{18} \mathrm{O} /{ }^{16} \mathrm{O}$ ratio in the sample or in the international standard, respectively. It should be mentioned that Coplen (2011) has suggested removing the factor of 1000 in order to harmonize the $\delta$ value with the SI system. The measurement precision is better than $0.15 \%$ for $\mathrm{C}$ and $\mathrm{O}$ isotope data based on replicate measurements of international standards (NBS-19; NBS-18) and inhouse reference materials. The stable oxygen isotope compositions of water samples are expressed as $\delta^{18} \mathrm{O}$ values in \%o relative to V-SMOW (Vienna Standard Mean Ocean Water). The analytical reproducibility is $\pm 0.1 \%$.

$\mathrm{Cr}, \mathrm{Mn}, \mathrm{Fe}, \mathrm{Cu}, \mathrm{Zn}, \mathrm{Sr}$ and $\mathrm{Pb}$ concentrations were determined in shell fragments gathered from the drill core using energy-dispersive $\mathrm{X}$-ray fluorescence (EDXRF). The measurements were performed using a Seifert diffraction tube with Ag anode and a Mo secondary target, operating at $40 \mathrm{kV}$ tube voltage and $50 \mathrm{~mA}$ current. Characteristic and scattered $\mathrm{X}$-rays were collected by a Ketek (Munich, Germany) silicon drift detector with an energy resolution of $150 \mathrm{eV}$ for Mn-K X-rays. The typical measuring life time was $6000 \mathrm{~s}$. The characteristic X-ray spectra obtained from the samples were evaluated by non-linear least-squares fitting, using the AXIL code (Vekemans et al. 1994). For quantitative analysis, the sensitivity curve of the measurement system was determined by measuring a series of Micromatter (Seattle, USA) standard thin foils. $\mathrm{A} \mathrm{CaCO}_{3}$ matrix was considered for the concentration calculations. The detection limits $\mathrm{DL}_{\mathrm{i}}$ for element i were calculated as

$$
D L_{i}=3 C_{i} \frac{\sqrt{B_{i}}}{N_{i}}
$$

where $\mathrm{Ci}, \mathrm{Ni}$ and $\mathrm{Bi}$ are the concentration, the net counts of the characteristic X-ray line and the corresponding background counts, respectively. The DL values reached for $\mathrm{CaCO}_{3}$ matrix and $6000 \mathrm{~s}$ measuring time are listed in Table 1.

\section{Results}

An attempt was made to supplement the age dates reported by Sümegi (2004) with AMS ${ }^{14} \mathrm{C}$ age dates. Thus, an additional set of 9 age dates were
Table 1

Detection limits of secondary-target XRF calculated for $\mathrm{CaCO}_{3}$ matrix and $6000 \mathrm{~s}$ live time

\begin{tabular}{|c|c|c|}
\hline Element & $\begin{array}{c}\text { Analytical } \\
\text { line }\end{array}$ & DL $(\boldsymbol{\mu g} / \mathbf{g})$ \\
\hline $\mathrm{Cr}$ & $\mathrm{K} \alpha$ & 36.1 \\
\hline $\mathrm{Mn}$ & $\mathrm{K} \alpha$ & 22.5 \\
\hline $\mathrm{Fe}$ & $\mathrm{K} \alpha$ & 14.0 \\
\hline $\mathrm{Ni}$ & $\mathrm{K} \alpha$ & 6.3 \\
\hline $\mathrm{Cu}$ & $\mathrm{K} \alpha$ & 4.7 \\
\hline $\mathrm{Zn}$ & $\mathrm{K} \alpha$ & 3.1 \\
\hline $\mathrm{Sr}$ & $\mathrm{K} \alpha$ & 1.1 \\
\hline $\mathrm{Pb}$ & $\mathrm{L} \alpha$ & 3.4 \\
\hline
\end{tabular}


gathered on Unio shells (Table 2). However, the results were not appropriate for establishing an age model, as the shells gave uniform age dates at $7395 \pm 279$ years $\mathrm{BP}$ (uncorrected ${ }^{14} \mathrm{C}$ ages, BP; Table 2). Possible reasons of the unusual age data will be evaluated in the section entitled Discussions.

Table 2

AMS ${ }^{14} \mathrm{C}$ age date measurement data

\begin{tabular}{llrrrr}
\hline Depth $(\mathbf{c m})$ & AMS lab code & pMC abs & \pm pMC & Age & \pm Age \\
\hline $350-360$ & 1544.1 .1 & 39.70 & 0.35 & 7421 & 71 \\
$360-370 *$ & 1828.1 .1 & 37.34 & 0.21 & 7913 & 46 \\
$380-390$ & 1545.1 .1 & 41.47 & 0.34 & 7071 & 66 \\
$390-400 *$ & 1829.1 .1 & 39.87 & 0.20 & 7387 & 40 \\
$450-460$ & 1546.1 .1 & 38.51 & 0.35 & 7665 & 72 \\
$530-540$ & 1547.1 .1 & 41.50 & 0.34 & 7064 & 67 \\
$580-590 *$ & 1830.1 .1 & 39.96 & 0.20 & 7368 & 40 \\
$590-600$ & 1548.1 .1 & 40.99 & 0.34 & 7164 & 68 \\
$660-670$ & 1549.1 .1 & 39.31 & 0.34 & 7500 & 69 \\
\hline
\end{tabular}

Asterisk denotes samples pretreated with dilute phosphoric acid to remove surficial carbonate contamination

Stable oxygen isotope compositions of water samples collected at Szolnok range from -11.1 to $-8.3 \%$ with a mean of $-9.7 \pm 0.6 \%$ (Table 3). The isotopic compositions show a seasonal fluctuation with the warm seasons relatively enriched in ${ }^{18} \mathrm{O}$. Within the dataset those samples collected in the warm seasons (April to October) gave a mean composition of $-9.4 \pm 0.7 \%$ (relative to V-SMOW). The modern shells have mean $\delta^{13} \mathrm{C}$ and $\delta^{18} \mathrm{O}$ values of $-11.8 \pm 0.6$ and $-9.6 \pm 0.3 \%$ o (relative to V-PDB), respectively, showing slight differences between the five different sampling locations along the Tisza river with the southernmost samples enriched in ${ }^{18} \mathrm{O}$ relative to the northern samples (Table 3, Fig. 1).

The original Unio shells are composed of aragonite that can be transformed to calcite and hence may suffer alterations, so the fossil shell fragments were checked for the preservation of aragonite by means of cathodoluminescence microscopy. The collected shells have preserved the original aragonite mineralogy

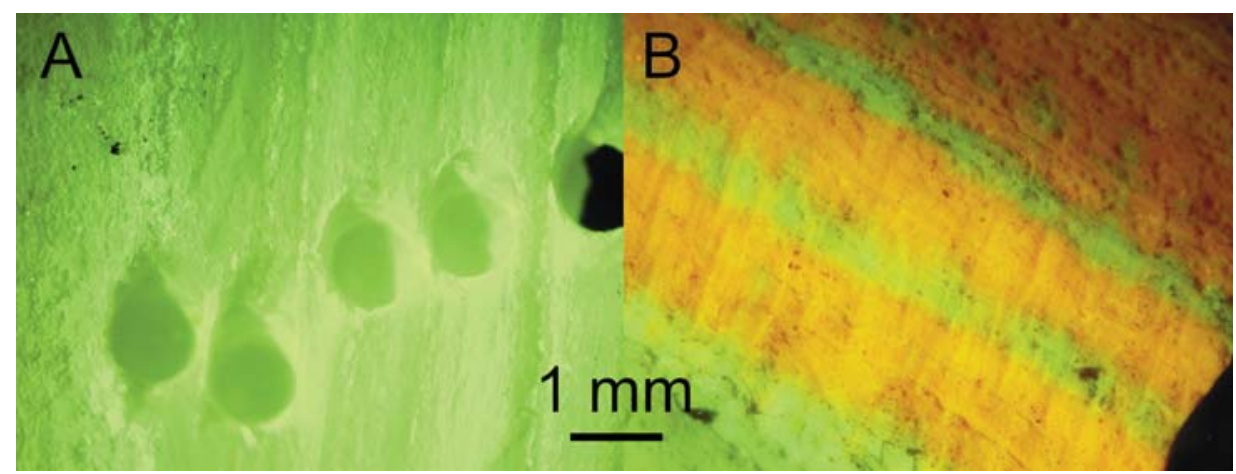


Table 3

Stable oxygen isotope compositions (in \%o relative to V-SMOW) of water samples collected at Szolnok and carbon and oxygen isotope compositions (in \%o relative to V-PDB) of living Unio shells collected at five locations along the Tisza river

\begin{tabular}{|c|c|c|c|c|c|}
\hline$\underline{\text { Date }}$ & $\delta^{18} \mathrm{O}$ & Date & $\delta^{18} \mathrm{O}$ & Date & $\delta^{18} \mathrm{O}$ \\
\hline 09.03 .2001 & -10 & 28.01 .2002 & -9.8 & 28.05 .2003 & -9.9 \\
\hline 12.03 .2001 & -10.1 & 12.02 .2002 & -9.8 & 04.06 .2003 & -9.5 \\
\hline 14.03 .2001 & -10.1 & 25.02 .2002 & -10 & 17.06 .2003 & -8.7 \\
\hline 16.03 .2001 & -10 & 12.03 .2002 & -10.1 & 25.06 .2003 & -8.9 \\
\hline 17.03 .2001 & -10 & 26.03 .2002 & -10 & 15.07 .2003 & -8.8 \\
\hline 18.03.2001 & -10 & 09.04.2002 & -9.8 & 29.07.2003 & -9.1 \\
\hline 19.03 .2001 & -9.9 & 23.04 .2002 & -10.2 & 12.08 .2003 & -8.8 \\
\hline 20.03 .2001 & -10 & 07.05 .2002 & -10.2 & 27.08 .2003 & -8.7 \\
\hline 21.03 .2001 & -9.9 & 22.05 .2002 & -9.8 & 09.09 .2003 & -8.3 \\
\hline 22.03 .2001 & -10 & 03.07 .2002 & -9.2 & 23.09 .2003 & -8.3 \\
\hline 23.03 .2001 & -10 & 16.07 .2002 & -9 & 07.10 .2003 & -8.6 \\
\hline 25.03 .2001 & -10.1 & 30.07 .2002 & -8.3 & 21.10 .2003 & -9.4 \\
\hline 27.03 .2001 & -10.1 & 13.08 .2002 & -8.7 & 03.11 .2003 & -9.7 \\
\hline 29.03 .2001 & -10.1 & 27.08 .2002 & -9.3 & 18.11.2003 & -10 \\
\hline 15.05 .2001 & -9.8 & 10.09 .2002 & -9.1 & 01.12 .2003 & -10.1 \\
\hline 29.05 .2001 & -9.6 & 24.09.2002 & -8.6 & 16.12 .2003 & -9.9 \\
\hline 12.06 .2001 & -9.3 & 08.10 .2002 & -9.5 & 13.01 .2004 & -10 \\
\hline 16.06 .2001 & -9 & 24.10 .2002 & -9.6 & 26.01 .2004 & -10.8 \\
\hline 10.07 .2001 & -9.6 & 04.11 .2002 & -9.6 & 10.02 .2004 & -10.3 \\
\hline 24.07 .2001 & -9 & 19.11 .2002 & -10.2 & 23.02 .2004 & -11 \\
\hline 07.08 .2001 & -9.1 & 02.12 .2002 & -10 & 09.03 .2004 & -11.1 \\
\hline 22.08 .2001 & -9 & 17.12 .2002 & -9.7 & 23.03 .2004 & -10.9 \\
\hline 04.09 .2001 & -9.2 & 30.12 .2002 & -9.9 & 07.04 .2004 & -10.8 \\
\hline 18.09 .2001 & -9.6 & 14.01 .2003 & -10.4 & 20.04 .2004 & -10.7 \\
\hline 02.10 .2001 & -8.8 & 27.01 .2003 & -10.1 & 04.05 .2004 & -10.6 \\
\hline 16.10 .2001 & -9.5 & 13.02 .2003 & -10.2 & 18.05 .2004 & -10.5 \\
\hline 29.10 .2001 & -9.2 & 24.02 .2003 & -10.6 & 02.06 .2004 & -10.2 \\
\hline 13.11 .2001 & -9.6 & 11.03 .2003 & -9.7 & 15.06 .2004 & -9.8 \\
\hline 26.11 .2001 & -9.3 & 25.03 .2003 & -10.9 & 28.06 .2004 & -9.3 \\
\hline 11.12 .2001 & -9.8 & 08.04 .2003 & -10.5 & 13.07.2004 & -9.4 \\
\hline 27.12 .2001 & -9.9 & 23.04 .2003 & -10.4 & 27.07 .2004 & -9.2 \\
\hline \multirow[t]{2}{*}{15.01 .2002} & -10.6 & 07.05 .2003 & -10.5 & & \\
\hline & $\delta^{13} \mathrm{C}$ & $\delta^{18} \mathrm{O}$ & & & \\
\hline Dombrád & -11.9 & -9.9 & & & \\
\hline Tokaj & -12.0 & -9.7 & & & \\
\hline Tiszacsege & -12.0 & -9.7 & & & \\
\hline Mindszent & -11.4 & -8.9 & & & \\
\hline Tiszasziget & -11.6 & -9.5 & & & \\
\hline
\end{tabular}

$\leftarrow$ Fig. 2

Cathodoluminescence microscopic pictures of fossil Unio shells from the drill core of Tiszapüspöki, Kartsú-ér. A: Well preserved aragonite shell from the depth of 440-450 cm. B: Partially calcitized shell from the depth of $640-650 \mathrm{~cm}$ 
on the basis of their green cathodoluminescence color (Fig. 2A), with only one exception (collected at the depth of $640-650 \mathrm{~cm}$ ) that showed orange luminescence color, indicating transformation to calcite (Fig. 2B).

Stable carbon and oxygen isotope compositions and trace element concentrations are listed in Table 4. Since each shell fragment was sampled at several points for stable isotope analyses, Table 4 also lists the number of analyses and standard deviations $(1 \sigma)$ of the average values for each shell. The stable isotope compositions are plotted as a function of depth in Fig. 3, where the size of sample markers are equivalent to the depth range covered $(10 \mathrm{~cm})$ by each sample. The $\mathrm{C}$ and $\mathrm{O}$ isotope compositions show major deviations at the 390-400 and $560-580 \mathrm{~cm}$ depth intervals, respectively. The calcitized shell sample of the depth interval of 640-650 $\mathrm{cm}$ has a slightly lower - although not exceptional $\delta^{13} \mathrm{C}$ value than the majority of the samples, whereas its $\delta^{18} \mathrm{O}$ value still fits those of the neighboring samples. This indicates that calcitization was not associated with important isotopic changes, but this sample was excluded from the

Table 4

Stable carbon and oxygen isotope compositions (in \%o relative to V-PDB) and trace element contents (in ppm) of Unio sp. shell fragments in the drill hole of the Kartsú-ér, Tiszapüspöki

\begin{tabular}{|c|c|c|c|c|c|c|c|c|c|c|c|c|c|}
\hline Depth (cm) & $\delta^{13} \mathrm{C}$ & Std. & $\delta^{18} \mathrm{O}$ & Std. & $\mathbf{N}$ & $\mathrm{Cr}$ & Mn & $\mathrm{Fe}$ & $\mathrm{Ni}$ & $\mathbf{C u}$ & $\mathbf{Z n}$ & $\mathrm{Sr}$ & $\mathbf{P b}$ \\
\hline $310-320$ & -11.6 & 0.8 & -9.3 & 0.8 & 5 & 58.3 & 168 & 265 & 7.1 & 16.6 & 45.2 & 386 & 40.7 \\
\hline $350-360$ & -10.1 & 1.2 & -8.6 & 0.6 & 6 & & & & & & & & \\
\hline $360-370$ & -13.2 & 0.9 & -9.5 & 0.8 & 7 & & 548 & 283 & 28.2 & 35.9 & 17.8 & 588 & 51.7 \\
\hline $380-390$ & -11.3 & 0.4 & -8.3 & 0.5 & 6 & 47.3 & 250 & 120 & 15.1 & 20.2 & 10.2 & 616 & 35.7 \\
\hline $390-400$ & -6.3 & 1.3 & -7.2 & 1.4 & 5 & 72.9 & 1429 & 112 & 7.3 & 12.8 & 14.7 & 512 & 40.8 \\
\hline $400-410$ & -12.1 & 1.2 & -9.6 & 0.4 & 5 & 45.3 & 209 & 171 & 9.3 & 8.1 & 26.5 & 504 & 39.4 \\
\hline $410-420$ & -9.9 & 0.4 & -8.8 & 0.5 & 4 & 62.3 & 323 & 110 & 9.0 & 12.9 & 8.2 & 897 & 47.2 \\
\hline $420-430$ & -11.8 & 1.0 & -9.3 & 0.9 & 5 & 44.5 & 198 & 94 & 7.9 & 10.5 & 12.1 & 343 & 32.6 \\
\hline $430-440$ & -11.7 & 0.3 & -8.7 & 0.3 & 8 & 77.9 & 657 & 116 & 4.6 & 10.3 & 8.9 & 541 & 44.0 \\
\hline $440-450$ & -10.9 & 0.1 & -8.4 & 0.6 & 3 & 54.3 & 722 & 107 & 6.8 & 13.2 & 8.0 & 513 & 44.6 \\
\hline $460-470$ & -12.7 & 1.3 & -8.5 & 0.4 & 6 & 37.4 & 485 & 94 & 5.9 & 11.7 & 4.1 & 494 & 41.6 \\
\hline $470-480$ & -12.3 & 1.3 & -8.3 & 2.7 & 5 & 63.4 & 708 & 106 & 6.2 & 10.6 & 6.7 & 497 & 40.8 \\
\hline $480-490$ & -11.0 & 1.0 & -9.8 & 1.6 & 7 & 63.6 & 381 & 166 & 7.7 & 14.5 & 9.4 & 638 & 47.7 \\
\hline $490-500$ & -11.3 & 0.4 & -9.5 & 1.0 & 5 & 23.4 & 50 & 109 & 6.0 & 9.9 & 6.3 & 457 & 36.0 \\
\hline $500-510$ & -13.6 & 0.6 & -9.3 & 0.4 & 5 & 51.3 & 337 & 105 & 7.9 & 13.0 & 5.2 & 627 & 51.8 \\
\hline $510-520$ & -10.5 & 0.6 & -9.6 & 0.9 & 5 & 63.9 & & 140 & 9.7 & 12.3 & 4.0 & 718 & 38.2 \\
\hline $530-540$ & -10.4 & 0.1 & -9.5 & 0.2 & 3 & 41.9 & 499 & 117 & 12.2 & 17.0 & 6.9 & 421 & 44.8 \\
\hline $540-550$ & -9.8 & 0.5 & -7.8 & 0.8 & 6 & 73.4 & 1299 & 154 & 17.1 & 18.0 & 6.3 & 630 & 54.0 \\
\hline $550-560$ & -10.6 & 0.6 & -8.5 & 0.5 & 6 & 66.2 & 710 & 126 & 16.7 & 25.0 & 10.2 & 448 & 52.2 \\
\hline $560-570$ & -9.3 & 1.0 & -4.3 & 3.6 & 6 & 31.9 & 1023 & 367 & 7.8 & 33.2 & 12.7 & 698 & 49.8 \\
\hline $570-580$ & -8.1 & 0.5 & -3.7 & 1.0 & 6 & 43.6 & 1651 & 359 & 18.1 & 50.5 & 13.2 & 361 & 30.9 \\
\hline $580-590$ & -8.9 & 1.6 & -8.1 & 1.8 & 6 & 67.2 & 616 & 107 & 7.0 & 12.3 & 6.1 & 454 & 48.5 \\
\hline $590-600$ & -10.5 & 1.8 & -8.3 & 1.1 & 7 & 52.4 & 763 & 141 & 4.5 & 12.9 & 7.2 & 573 & 51.8 \\
\hline $600-610$ & -11.1 & 1.2 & -9.2 & 1.5 & 5 & 32.5 & 383 & 95 & 5.5 & 9.2 & 3.7 & 409 & 42.1 \\
\hline $630-640$ & -11.0 & 0.3 & -8.4 & 0.5 & 3 & 42.0 & 1443 & 356 & 52.2 & 98.0 & 35.0 & 434 & 81.9 \\
\hline $640-650$ & -12.7 & 1.1 & -8.6 & 1.2 & 6 & 53.4 & 542 & 139 & 13.5 & 18.5 & 7.6 & 318 & 34.3 \\
\hline $650-660$ & & & & & & 68.0 & 926 & 108 & 9.2 & 16.9 & 7.2 & 503 & 43.7 \\
\hline $660-670$ & -8.8 & 0.3 & -8.6 & 0.3 & 5 & 24.8 & 934 & 115 & 4.4 & 9.1 & 6.1 & 371 & 37.7 \\
\hline
\end{tabular}



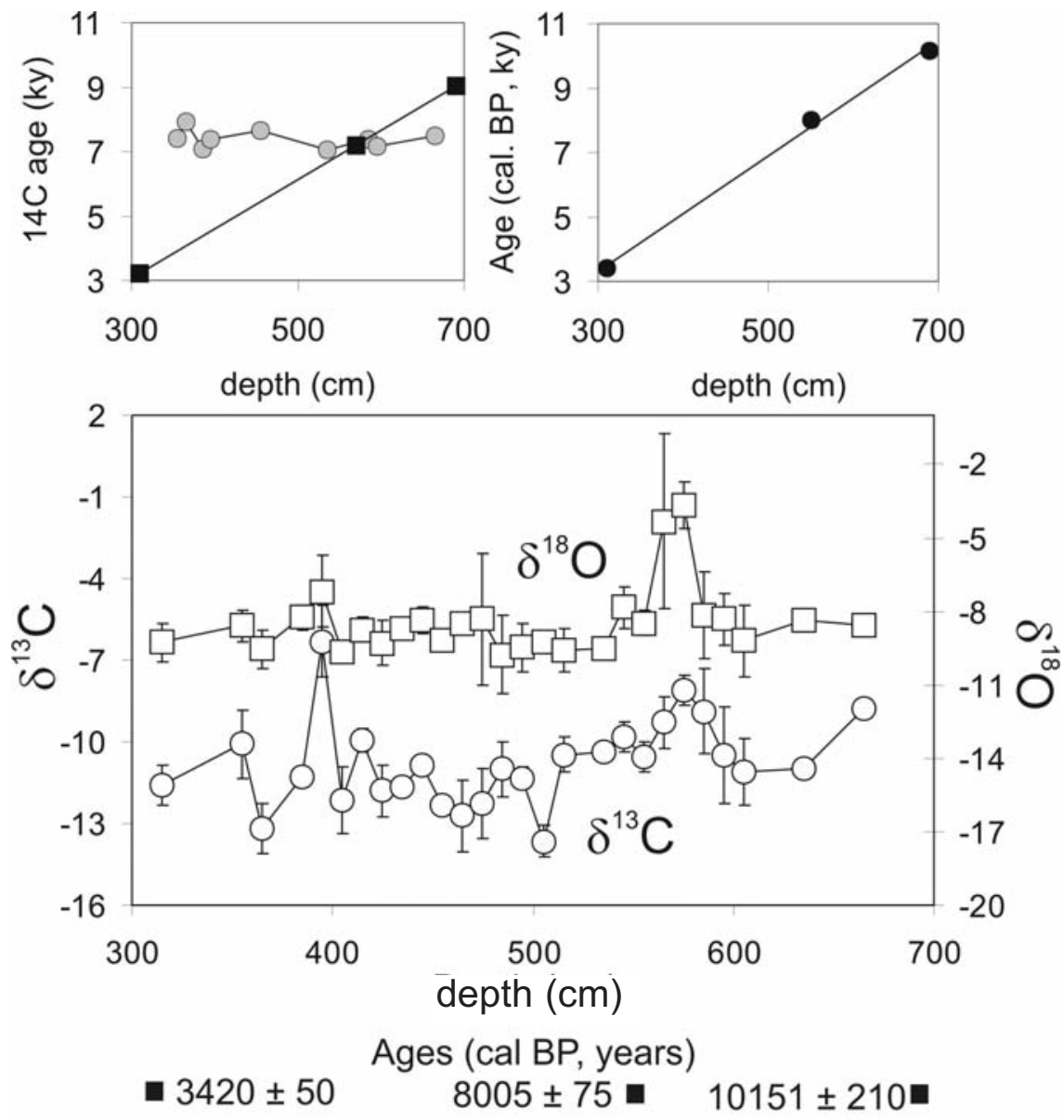

\begin{tabular}{|c|c|c|c|c|}
\hline 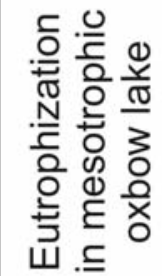 & 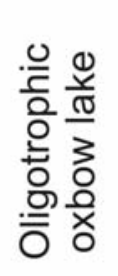 & 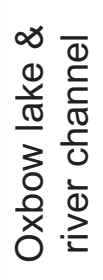 & 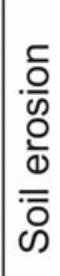 & 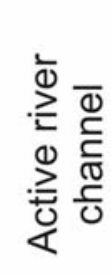 \\
\hline
\end{tabular}

Fig. 3

Age-depth models, stable carbon and oxygen isotope compositions (in \%o relative to V-PDB) of fossil shells collected at Kartsú-ér, Tiszapüspöki, and sedimentary facies classification reported by Sümegi (2004) are shown as a function of depth. Age data of Sümegi (2004) are plotted as solid squares (uncalibrated ${ }^{14} \mathrm{C}$ ages) and circles (calibrated BP ages) as a function of depth along with new AMS uncalibrated ${ }^{14} \mathrm{C}$ ages obtained in this work (grey filled circles). The calibrated ${ }^{14} \mathrm{C}$ ages are also given with their stratigraphic positions above the facies classification diagram 
discussion - and the plot of Fig. 3 - for the sake of safe interpretation. Although the extent of isotope shift is not the same for $\delta^{13} \mathrm{C}$ and $\delta^{18} \mathrm{O}$, the high $\delta^{13} \mathrm{C}$ values are generally associated with elevated $\delta^{18} \mathrm{O}$ values, and vice versa. This can be demonstrated by correlation coefficients calculated for the dataset. The obtained linear regression $\mathrm{R}^{2}$ values decrease from 0.6 to 0.4 , if the outlier samples (see above) are excluded from the calculation. However, even with the outliers excluded, the $\mathrm{C}$ and $\mathrm{O}$ isotope compositions show a slight positive correlation.

The analyzed trace element contents (excepting $\mathrm{Cr}$ that showed a random fluctuation) are plotted in Fig. 4 along with the stable isotope compositions. $\mathrm{Fe}, \mathrm{Ni}$, $\mathrm{Cu}, \mathrm{Zn}$ and $\mathrm{Pb}$ show elevated concentrations and large fluctuations at the lower $(>560 \mathrm{~cm})$ and the upper $(<360 \mathrm{~cm})$ parts of the section, whereas the $\mathrm{Mn}$ and $\mathrm{Sr}$ contents show slight decrease and increase, respectively, with fluctuations. The depth intervals where elevated $\mathrm{Fe}, \mathrm{Ni}, \mathrm{Cu}, \mathrm{Zn}$ and $\mathrm{Pb}$ concentrations appear are marked as grey bars in Fig. 4. The isotopic and trace element data define two major groups in principal component analyses $\left(\delta^{13} \mathrm{C}-\delta{ }^{18} \mathrm{O}-\mathrm{Sr}-\mathrm{Cr}-\mathrm{Mn}\right.$ and Fe-Ni$\mathrm{Cu}-\mathrm{Zn}-\mathrm{Pb}$, Fig. 5), although statistically significant correlations appear only for the latter element group (Table 5).

Table 5

$\mathrm{R}^{2}$ values for linear regression correlations between stable $\mathrm{C}$ and $\mathrm{O}$ isotope compositions and trace element contents

\begin{tabular}{|c|c|c|c|c|c|c|c|c|c|c|}
\hline \multicolumn{11}{|c|}{ All data } \\
\hline & $\delta^{13} \mathrm{C}$ & $\delta^{18} \mathrm{O}$ & $\mathrm{Cr}$ & $\mathrm{Mn}$ & $\mathrm{Fe}$ & $\mathrm{Ni}$ & $\mathrm{Cu}$ & $\mathrm{Zn}$ & $\mathrm{Sr}$ & $\mathrm{Pb}$ \\
\hline$\delta^{13} \mathrm{C}$ & & 0.31 & 0.01 & 0.29 & 0.06 & 0.00 & 0.02 & 0.00 & 0.00 & 0.00 \\
\hline$\delta^{18} \mathrm{O}$ & 0.31 & & 0.01 & 0.21 & $\underline{0.41}$ & 0.02 & 0.16 & 0.00 & 0.00 & 0.00 \\
\hline $\mathrm{Cr}$ & 0.01 & 0.01 & & 0.05 & 0.04 & 0.00 & 0.02 & 0.00 & 0.10 & 0.02 \\
\hline $\mathrm{Mn}$ & 0.29 & 0.21 & 0.05 & & 0.16 & 0.13 & 0.18 & 0.00 & 0.02 & 0.04 \\
\hline $\mathrm{Fe}$ & 0.06 & $\underline{0.41}$ & 0.04 & 0.16 & & 0.31 & $\underline{0.59}$ & 0.36 & 0.00 & 0.11 \\
\hline $\mathrm{Ni}$ & 0.00 & 0.02 & 0.00 & 0.13 & 0.31 & & $\underline{0.86}$ & 0.21 & 0.02 & $\underline{0.47}$ \\
\hline $\mathrm{Cu}$ & 0.02 & 0.16 & 0.02 & 0.18 & 0.59 & $\underline{0.86}$ & & 0.23 & 0.02 & 0.42 \\
\hline $\mathrm{Zn}$ & 0.00 & 0.00 & 0.00 & 0.00 & 0.36 & 0.21 & 0.23 & & 0.06 & 0.08 \\
\hline $\mathrm{Sr}$ & 0.00 & 0.00 & 0.10 & 0.02 & 0.00 & 0.02 & 0.02 & 0.06 & & 0.05 \\
\hline $\mathrm{Pb}$ & 0.00 & 0.00 & 0.02 & 0.04 & 0.11 & 0.47 & $\underline{0.42}$ & 0.08 & 0.05 & \\
\hline \multicolumn{11}{|c|}{ Without $\delta^{18}$ O outliers of the $560-580$ depth interval } \\
\hline & $\delta^{13} \mathrm{C}$ & $\delta^{18} \mathrm{O}$ & $\mathrm{Cr}$ & $\mathrm{Mn}$ & $\mathrm{Fe}$ & $\mathrm{Ni}$ & $\mathrm{Cu}$ & $\mathrm{Zn}$ & $\mathrm{Sr}$ & $\mathrm{Pb}$ \\
\hline$\delta^{13} \mathrm{C}$ & & 0.28 & 0.06 & 0.21 & 0.00 & 0.00 & 0.00 & 0.00 & 0.01 & 0.00 \\
\hline$\delta^{18} \mathrm{O}$ & 0.28 & & 0.13 & 0.12 & 0.00 & 0.03 & 0.03 & 0.01 & 0.00 & 0.05 \\
\hline $\mathrm{Cr}$ & 0.06 & 0.13 & & 0.12 & 0.00 & 0.00 & 0.01 & 0.00 & 0.17 & 0.02 \\
\hline $\mathrm{Mn}$ & 0.21 & 0.12 & 0.12 & & 0.05 & 0.12 & 0.11 & 0.00 & 0.04 & 0.11 \\
\hline $\mathrm{Fe}$ & 0.00 & 0.00 & 0.00 & 0.05 & & $\underline{0.59}$ & 0.65 & $\underline{0.70}$ & 0.02 & $\underline{0.42}$ \\
\hline $\mathrm{Ni}$ & 0.00 & 0.03 & 0.00 & 0.12 & $\underline{0.59}$ & & $\underline{0.94}$ & 0.21 & 0.01 & $\underline{0.61}$ \\
\hline $\mathrm{Cu}$ & 0.00 & 0.03 & 0.01 & 0.11 & $\underline{0.65}$ & $\underline{0.94}$ & & 0.25 & 0.01 & $\underline{0.68}$ \\
\hline $\mathrm{Zn}$ & 0.00 & 0.01 & 0.00 & 0.00 & $\underline{0.70}$ & 0.21 & 0.25 & & 0.06 & 0.10 \\
\hline $\mathrm{Sr}$ & 0.01 & 0.00 & 0.17 & 0.04 & 0.02 & 0.01 & 0.01 & 0.06 & & 0.02 \\
\hline $\mathrm{Pb}$ & 0.00 & 0.05 & 0.02 & 0.11 & $\underline{0.42}$ & 0.61 & $\underline{0.68}$ & 0.10 & 0.02 & \\
\hline
\end{tabular}

Bold and underlined values denote correlations with $\mathrm{R}^{2}$ values higher than 0.4 
Fig. 4

Stable isotope (see Fig. 3) and trace element compositions of fossil shells collected at Kartsú-ér, Tiszapüspöki, as a function of depth with age data and sedimentary facies classification Sümegi (2004)
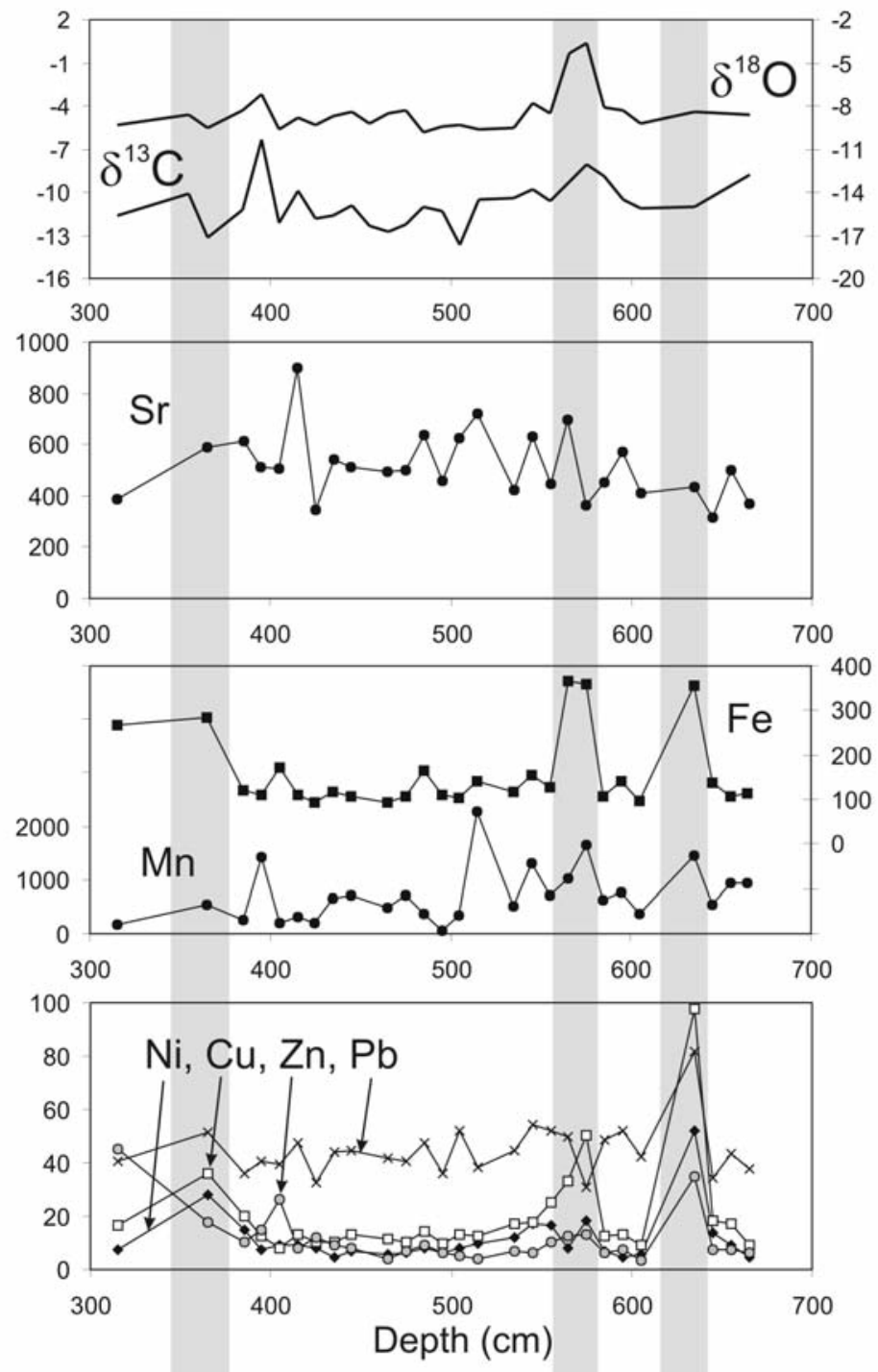

Ages (cal BP, years)

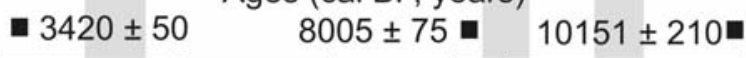

\begin{tabular}{|c|c|c|c|c|}
\hline 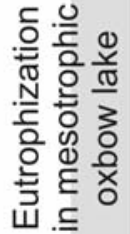 & 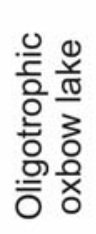 & 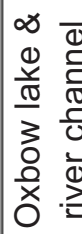 & 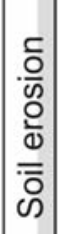 & 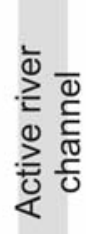 \\
\hline
\end{tabular}

Central European Geology 55, 2012 


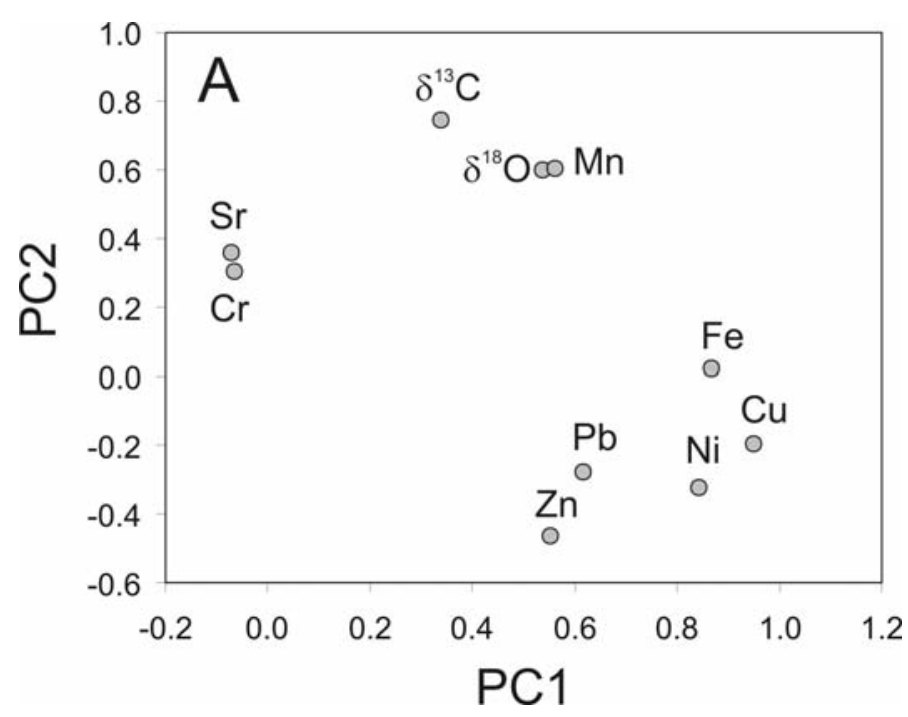

Fig. 5

Results of principal component analyses of the geochemical data

\section{Discussion}

Age model for the Kartsú-ér section

Sümegi (2004) reported three conventional ${ }^{14} \mathrm{C}$ age dates obtained for wood fragments from the Kartsú-ér section at Tiszapüspöki that show a very good linear fitting with an $\mathrm{R}^{2}$ value of 0.99 (Fig. 3). Although dating sediments of fluvial environments such as oxbow lakes can be problematic due to the resedimentation and alteration of organic fragments, the good linear age-depth relationship indicates that the data represent valid ages. Additionally, the sedimentation rate calculated from the age dates and sampling depths $(0.56 \mathrm{~mm}$ $\mathrm{yr}^{-1}$ ) is in good agreement with the sedimentation rates reported by Sümegi (2007) for fluvial and lacustrine environments of central and eastern Hungary. In order to supplement the limited age dataset, an additional set of 9 AMS 14C analyses was obtained on Unio shell fragments, but with rather equivocal results. The uniform age dates yielded $(7395 \pm 279$ years BP) and the non-stratigraphic order of the age dates (see Fig. 3) may be related both to primary and secondary effects. The first effect that must be evaluated is secondary alteration. The preservation of aragonite in the shells' structure excludes the possibility of severe alteration. The presence of surficial carbonate may also deteriorate the sensitive AMS analyses, but an acid pretreatment was also used for three samples that gave the same age range as the non-treated samples, excluding this possibility as well. The third process that may result in non-stratigraphic order of age dates is resedimentation of shells and mixing during the drilling process. We can exclude drilling-related mixing as this was carefully avoided during the cutting of the 
core. Re-sedimentation of shells may have occurred, but in this case the shells would be generally older than expected on the basis of the linear age model, while the shells with the same virtual age are scattered along the entire core with data both older and younger than expected.

The last possibility is that the shells contain a dominating fraction of dead carbon that deteriorates the results. This is possible as the study site is situated in a general groundwater upwelling area where deep groundwater with old dissolved carbon is mixed with the surface waters. Although we do not have any direct evidence for this effect, this process may explain the unusual age dates. Although ${ }^{14} \mathrm{C}$ age dating of freshwater mussel shells have been successfully conducted at other locations (Demény et al. 2012), the results indicate that the present study site may not be appropriate for this purpose. Hence the age model based on the three conventional age dates will be used in the following discussion.

\section{Reflection of environmental conditions in shell compositions}

It can generally be assumed that the $\mathrm{C}$ and $\mathrm{O}$ isotope compositions of the mussel shells of the Unio sp. record environmental parameters such as temperature and humidity (e.g. Dettman et al. 1999; Verdegaal et al. 2005; Carroll and Romanek 2008; Versteegh et al. 2009; Schöne and Fiebig 2009; Schöll-Barna et al. 2012). However, local data should be gathered to investigate whether the shells collected at a given environment operate the same way as at other locations. Thus, we compared stable isotope compositions of shell carbonates with water compositions and meteorological data of the region. The most important environmental parameter in the life of bivalves is temperature. Unio shells cease growing below a water temperature of about $12-13{ }^{\circ} \mathrm{C}$ (Dettman et al. 1999; Versteegh et al. 2010b; Schöll-Barna et al. 2012), i.e. in the cold season, usually from November to March (Lajter et al. 2010). Thus, oxygen isotope compositions obtained for waters collected in the warm seasons were used to calculate temperatures at which equilibrium between shell aragonite and water could have taken place. Using the equation of Dettman et al. (1999) and the mean $\delta^{18} \mathrm{O}$ (water) value of $-9.4 \pm 0.7 \%$, the equilibrium temperature would be $21.6 \pm 1.4{ }^{\circ} \mathrm{C}$, which is in good agreement with the water temperature range of 19 to $22^{\circ} \mathrm{C}$ observed for the warm seasons (Lajter et al. 2010). Further, water temperature increases southward along the river flow (Konecsny 2003; Lajter et al. 2010), indicating a continuous evolution of river water along the flow stream. This is also reflected in the $\mathrm{C}$ and $\mathrm{O}$ isotope compositions of modern shells that show ${ }^{13} \mathrm{C}$ - and ${ }^{18} \mathrm{O}$ enrichment in the southernmost locations. The enrichment in heavy isotopes is related to water evaporation, using the data of lake-dwelling shells (Schöll-Barna et al. 2012) as an analogue. These observations suggest that the isotope compositions of the Unio shells of the Tisza river and its region do reflect 
environmental conditions, and the fossil equivalents can be used to assess past environmental changes.

\section{Environmental changes recorded by fossil shells}

Stable carbon isotope compositions of freshwater bivalve shells are determined by internal and external factors. One internal effect is the incorporation of ${ }^{12} \mathrm{C}$ enriched metabolic carbon into the carbonate shell that is less significant in the young shells, whereas it becomes stronger in the adult stages, causing a negative $\delta^{13} \mathrm{C}$ change during the growth of the shell. Although based on a lake environment, Schöll-Barna et al. (2012) demonstrated the metabolic effect in living mussels of the Unio sp. of Lake Balaton (about $200 \mathrm{~km}$ to the west of Tiszapüspöki). Contrary to carbon isotope compositions, $\delta^{18} \mathrm{O}$ values reflect environmental conditions in the shells (Schöll-Barna et al. 2012) and follow the equilibrium oxygen isotope fractionation between aragonite and water determined by Dettman et al. (1999). This observation suggests that the shell fragments collected and analyzed in this study should be classified in terms of distance from the umbo. Figure $6 \mathrm{~A}$ shows the $\mathrm{C}$ and $\mathrm{O}$ isotope compositions of the studied shells with distinction between samples from marginal and central parts of the shells. As the plot indicates, there is no difference between the two data sets; thus the variations observed cannot be attributed to metabolic fractionations.

Another important piece of information that freshwater bivalve shells can carry is the internal isotopic variation. The sizes of shell fragments constrain the analyzed pieces to a time-span of 1-2 years. In case of extremely strong seasonal variations in temperature and precipitation, the internal fluctuations within the shell fragments can increase (Schöll-Barna et al. 2012). Thus, in time periods with enhanced seasonal differences the shells would have larger internal scatter in the $\delta^{13} \mathrm{C}$ and $\delta^{18} \mathrm{O}$ values. Fig. $6 \mathrm{~B}$ shows the standard deviations of the analyses obtained for individual shell fragments. The figure indicates only random variation upsection without signs of long-term seasonality changes.

Figures 3 and 4 show the isotopic compositions and trace element contents in the studied section together with depositional ages and sedimentary environments determined by Sümegi (2004). Although the age-depth model is based on only three data, they fit a linear regression line rather well, so the ages estimated with linear interpolation can be used. Although most of the correlations are not significant (Table 5), the isotopic and trace element data show some systematic changes. The open-water fluvial system characterizing the early part of the section (below $570 \mathrm{~cm}$ ) was associated with elevated trace element contents, pointing to the presence of detrital material eroded from the Carpathian Mountains where ore deposits are generally known to exist. Within the soilerosion horizon $(540-560 \mathrm{~cm})$ assumed on the basis of sedimentary characteristics (Sümegi 2004), a large positive $\delta^{18} \mathrm{O}$ shift appears, indicating either an increase of 
Fig. 6

A: Stable $\mathrm{C}$ and $\mathrm{O}$ isotope compositions (in \%o relative to VPDB) of the fossil shells collected at Kartsú-ér, Tiszapüspöki, with distinction between samples from marginal and central parts of the shells. B: Standard deviations of the analyses obtained for individual shell fragments

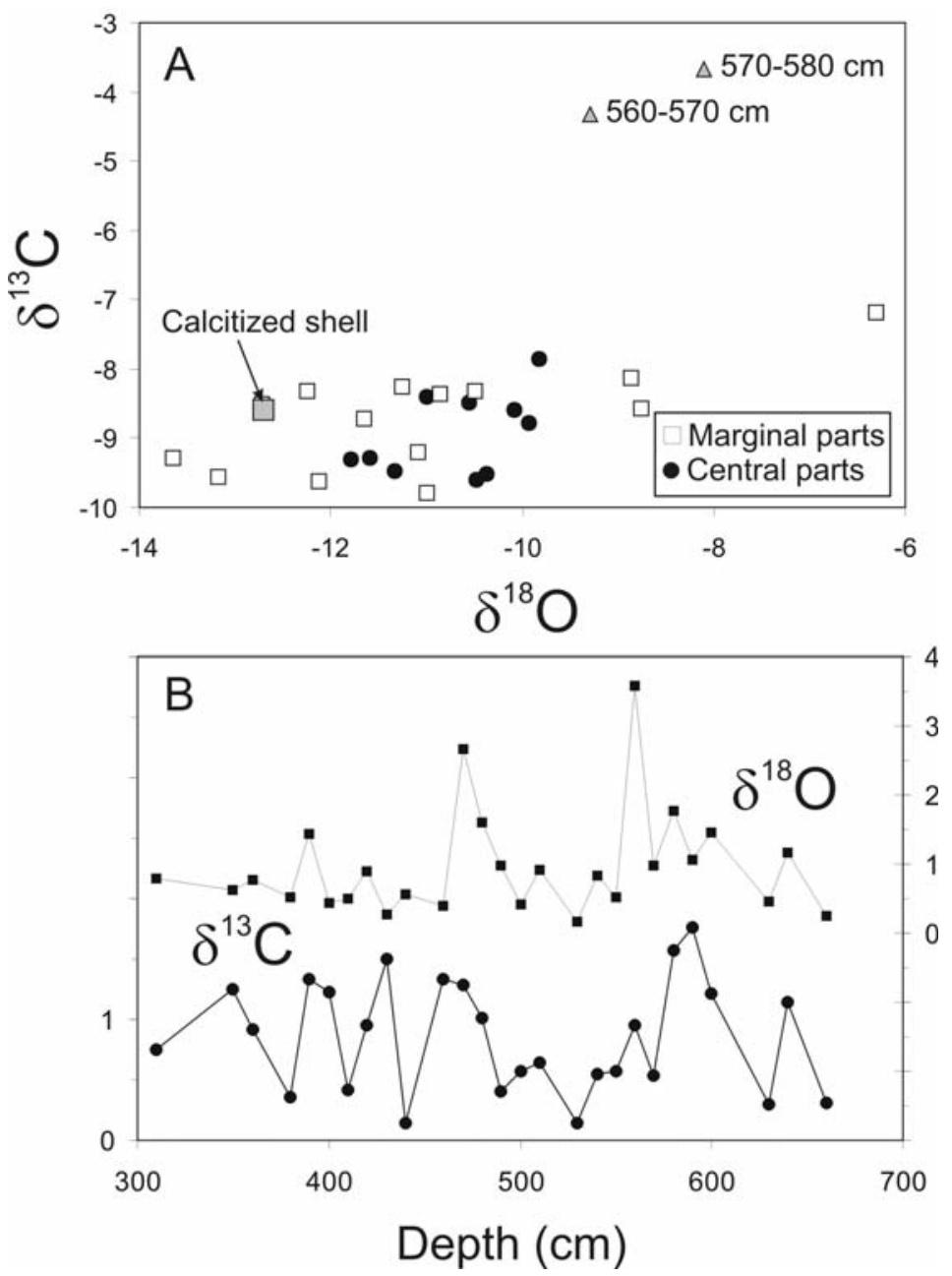

${ }^{18} \mathrm{O}$-enriched detrital sedimentary carbonate material that suddenly shifted the oxygen isotope composition of dissolved carbonate in the system, or a strong evaporation related to increased aridity. Interestingly, using linear interpolation between the ages reported by Sümegi (2004), the inferred erosion took place at about $8150 \pm 100$ years $\mathrm{BP}$, coinciding with the well-known $8.2 \mathrm{ky}$ event that is considered as a cold and wet phase in the Carpathian Basin (Magyari et al. 2009). Beside the $\mathrm{C}$ and $\mathrm{O}$ isotope shift, $\mathrm{Fe}, \mathrm{Mn}$ and $\mathrm{Cu}$ contents are also high in the shells in this section part, pointing again to the increase weathering of detrital material and/or evaporation-related rise in the concentration of dissolved ions.

Between 420 and $550 \mathrm{~cm}$, corresponding to about 5.5 to $7.7 \mathrm{ky} \mathrm{BP}$, the trace element concentrations and stable isotope values are rather low and less variable than before and after this period. On the basis of earlier studies ok freshwater 
mollusks, negative carbon and oxygen isotope shifts indicate cooler and/or wetter conditions, with decreased evaporation (Verdegaal et al. 2005; Versteegh et al. 2010a, b; Schöll-Barna et al. 2012). This period overlaps a major change in the sedimentary environment of the Tiszapüspöki location, with the formation of an oxbow lake. The development of the lake may rather suggest increased trace element concentration in the lake water due to evaporation; thus, the low concentrations observed would indicate increased precipitation that diluted the lake water. These pieces of information collectively suggest increased humidity in the period of 5.5 to $7.6 \mathrm{ky} \mathrm{BP}$.

The assumed humidity increase is also supported by the pollen analytical results presented by Sümegi (2004), who detected a major change in the section at about $500 \mathrm{~cm}$. Below this depth the pollen assemblage is dominated by Quercus, indicating relatively dry conditions. The subsequent increase in the Pinus and Fagus assemblage suggests elevated humidity, in agreement with the stable isotope and trace element data.

An additional correlation between the Tiszapüspöki section and a regional reference, the COMNISPA record, has been detected. Figure 7 shows the 5-point running mean of the $\mathrm{C}$ and $\mathrm{O}$ isotope compositions of the shells and the composite $\delta^{18} \mathrm{O}$ record of three stalagmites from the Spannagel Cave (Austria; Vollweiler et al. 2006). The COMNISPA record has been interpreted as a proxy for the so-called North Atlantic Oscillation (NAO; Hurrell 1995), with low $\delta^{18} \mathrm{O}$ values attributed to increased winter precipitation in the Alps during positive NAO

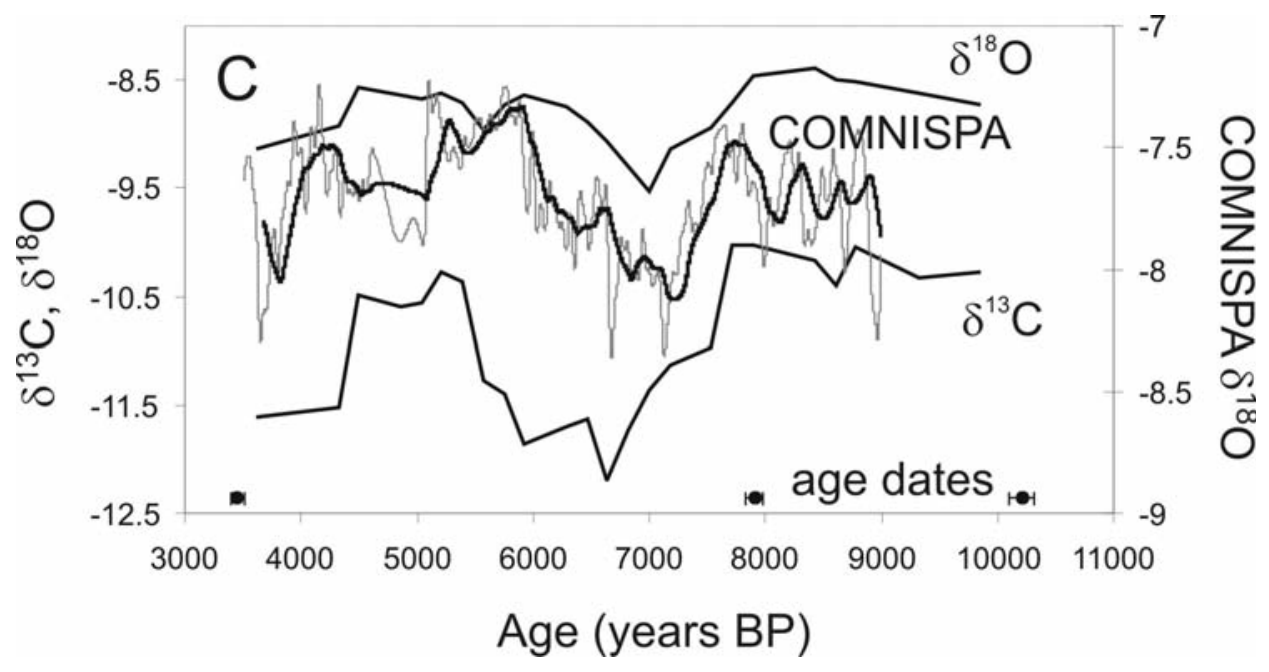

Fig. 7

Three-point running means of stable $\mathrm{C}$ and $\mathrm{O}$ isotope compositions of the fossil shells collected at Kartsú-ér, Tiszapüspöki, and stable oxygen isotope compositions (with their 200-year running mean shown as thick black line) of the COMNISPA record (Spannagel Cave, Austria; Vollweiler et al. 2006). All isotopic compositions are in \%o relative to V-PDB 
stages (i.e. in periods with elevated pressure difference between Iceland and the Azores area; Hurrell 1995). As Demény et al. (2012) have pointed out, the influence of NAO activity on the climate of the Carpathian Basin region can be traced back through the most of the Holocene, although it is thought to affect mainly winter humidity, whereas the bivalves studied in this paper secreted their shell material in the warm seasons. Based on the correspondence of the Tiszapüspöki and the COMNISPA records, it may be assumed that the $\mathrm{NAO}^{+}$ period between $\sim 6$ and $8 \mathrm{ky}$ (negative $\delta^{18} \mathrm{O}$ shift in the COMNISPA curve) was associated with a domination of humid summers.

Interestingly, a recent study on Baltic sea mollusks covering the age range of 6000 to 4300 years BP (Borówka et al. 2012) has detected a relatively cold period around $5 \mathrm{ky}$ BP. Since this period was characterized by relatively elevated $\delta^{18} \mathrm{O}$ values in the COMNISPA record (Fig. 7), it is thought to be associated with a negative NAO stage, i.e. cooler conditions, in accordance with the observations of Borówka et al. (2012). Although the present conclusion is based on one site with a rather poor age model, the relatively good fit of the different records indicate that the Tiszapüspöki dataset may be used in a regional paleoclimate evaluation, and that the conclusion drawn may deserve further study.

The uppermost part of the Tiszapüspöki-Kartsú-ér section is characterized by elevated trace element contents in the shells, but only slight elevations in the stable isotope compositions compared to the layers around $500 \mathrm{~cm}$. The elevated trace element contents could be related to increased evaporation, but this contradicts the stable isotope values. Another possibility is human activity suggested by Sümegi (2004), that may have caused enhanced erosion in the environment and may have also released ore-related elements. The present dataset is too limited to firmly resolve this question.

\section{Conclusions}

Modern shells collected at five locations along the Tisza river have stable isotope compositions that reflect ambient conditions, such as water temperature and evaporation. Stable $\mathrm{C}$ and $\mathrm{O}$ isotope compositions as well as trace element contents ( $\mathrm{Cr}, \mathrm{Mn}, \mathrm{Fe}, \mathrm{Ni}, \mathrm{Cu}, \mathrm{Zn}, \mathrm{Sr}, \mathrm{Pb}$ ) of fossil shells of the Unio sp. collected from a core drilled at Tiszapüspöki show systematic variations. Below $570 \mathrm{~cm}$, sedimentary layers are characterized by relatively elevated and fluctuating trace element contents, in accordance with the fluvial sedimentary environment. A soil erosion horizon assumed on the basis of sedimentary characteristics also appears in the $\mathrm{C}$ and $\mathrm{O}$ isotope compositions, indicating higher amount of marine sedimentary carbon in the river water derived from weathering of limestone or increased evaporation due to more arid climate conditions. Between 420 and 550 $\mathrm{cm}$ (corresponding to about 5.5 to $7.7 \mathrm{ky} \mathrm{BP}$ on the basis of age data published by Sümegi 2004) both the trace element contents and stable isotope compositions are less variable compared to earlier layers. The data collectively suggest increased summer humidity in this period that resulted in dilution of river water and 
decreased evaporation. Finally, the uppermost layers are characterized again by elevated trace element contents without concomitant stable isotope changes that could be related to human activity.

\section{Acknowledgements}

This study was financially supported by the Hungarian Scientific Research Fund (OTKA K-68343). The authors are deeply indebted to Mihály Molnár (MTA ATOMKI) for performing the ${ }^{14} \mathrm{C}$ AMS analyses and to the reviewers for their helpful reviews.

\section{References}

Al-Aasm, I.S., J.D. Clarke, B.J. Fryer 1998: Stable isotopes and heavy metal distribution in Dreissena polymorpha (zebra mussels) from western basin of Lake Erie, Canada. - Environmental Geology, 33, pp. 122-142.

Anadón, P., R. Utrilla, A. Vázquez, M. Martín-Rubio, J. Rodriguez-Lázaro, F. Robles 2008: Paleoenvironmental evolution of the Pliocene Villarroya Lake, northern Spain, from stable isotopes and trace-element geochemistry of ostracods and molluscs. - Journal of Paleolimnology, 39, pp. 399-419.

Apolinarska, K. 2009a: Reconstructions of the early and middle Holocene climate and environment based on $\delta^{13} \mathrm{C}$ and $\delta^{18} \mathrm{O}$ records in biogenic carbonates; Lake Niepruszewskie, western Poland. - Acta Geologica Polonica, 59, pp. 359-370.

Apolinarska, K. 2009b: $\delta^{13} \mathrm{C}$ and $\delta^{18} \mathrm{O}$ isotope investigation of the Late Glacial and early Holocene biogenic carbonates from the Lake Lednica sediments, western Poland. - Acta Geologica Polonica, 59, pp. 111-121.

Bailey, T.R., C.H. Lear 2006: Testing the effect of carbonate saturation on the $\mathrm{Sr} / \mathrm{Ca}$ of biogenic aragonite: A case study from the River Ehen, Cumbria, UK. - Geochemistry Geophysics Geosystems, 7, Q03019.

Barbin, V. 2000: Cathodoluminescence of carbonate shell: biochemical vs. diagenetic process. In: Pagel, M., V. Barbin, P. Blanc, D. Ohnenstetter (Eds): Cathodoluminescence in Geosciences. Springer-Verlag, Berlin, pp. 303-329.

Baroni, C., G. Zanchetta, A.E. Fallick, A. Longinelli 2006: Mollusca stable isotope record of a core from Lake Frassino, northern Italy: hydrological and climatic changes during the last $14 \mathrm{ka}$. The Holocene, 16, pp. 827-837.

Bar-Yosef Mayer, D.E., M.J. Leng, D.C. Aldridge, C. Arrowsmith, B.A. Gümüs, H.J. Sloane 2011: Modern and early-middle Holocene shells of the freshwater mollusc Unio, from Çatalhöyük in the Konya Basin, Turkey: preliminary palaeoclimatic implications from molluscan isotope data. - Journal of Archaeological Science, 39, pp. 76-83.

Borówka, R.K., W. Strobel, S. Halas 2012: Stable isotope composition of subfossil Cerastoderma glaucum shells from the Szczecin Bay brackish deposits and its palaeogeographical implications (South Baltic Coast, Poland). - Quaternary Research, 77, pp. 245-250.

Bucci, J.P., W.J. Showers, B. Genna, J.F. Levine 2009: Stable oxygen and carbon isotope profiles in an invasive bivalve (Corbicula fluminea) in North Carolina watersheds. - Geochimica et Cosmochimica Acta, 73, pp. 3234-3247.

Carroll, M., C.S. Romanek 2008: Shell layer variation in trace element concentration for the freshwater bivalve Elliptio complanata. - Geo-Marine Letters, 28, pp. 369-381.

Carroll, M.L., B.J. Johnson, G.A. Henkes, K.A. McMahon, A. Voronkov, W.G. Ambrose Jr. S.G. Denisenko 2009: Bivalves as indicators of environmental variation and potential anthropogenic impacts in the southern Barents Sea. - Marine Pollution Bulletin, 59, pp. 193-206.

Coplen, T.B. 2011: Guidelines and recommended terms for expression of stable-isotope-ratio and gasratio measurement results. - Rapid Communications in Mass Spectrometry, 25, pp. 2538-2560. 
Cravo, A., P. Foster, C. Almeida, M.J. Bebianno, R. Company 2008: Metal concentrations in the shell of Bathymodiolus azoricus from contrasting hydrothermal vent fields on the Mid-Atlantic Ridge. Marine Environmental Research, 65, pp. 338-348.

Davis, LG., K. Muehlenbachs 2001: A Late Pleistocene to Holocene record of precipitation reflected in Margaritifera falcata shell $\delta^{18} \mathrm{O}$ from three archaeological sites in the lower Salmon River Canyon, Idaho. - Journal of Archaeological Science, 28, pp. 291-303.

Demény, A., Gy. Czuppon, Z. Siklósy, Sz. Leél-Őssy, K. Lin, C.-C. Shen, K. Gulyás 2012: Mid-Holocene climate conditions and moisture source variations based on stable $\mathrm{H}, \mathrm{C}$ and $\mathrm{O}$ isotope compositions of speleothems in Hungary. - Quaternary International (in press)

Dettman, D.L., K.C. Lohmann 1993: Seasonal change in Paleogene surface water $\delta^{18} \mathrm{O}$ : Fresh-water bivalves of Western North America. - Geophysical Monograph (Climate Change in Continental Isotopic Records), 78, pp. 153-163.

Dettman, D.L., A.K. Reische, K.C. Lohmann 1999: Controls on the stable isotope composition of seasonal growth bands in aragonitic fresh-water bivalves (Unionidae). - Geochimica et Cosmochimica Acta, 63, pp. 1049-1057

Dick, D., E. Philipp, M. Kriews, D. Abele 2007: Is the umbo matrix of bivalve shells (Laternula elliptica) a climate archive? - Aquatic Toxicology, 84, pp. 450-456.

Epstein, S., T. Mayeda 1953: Variation of ${ }^{18} \mathrm{O}$ content of waters from natural sources. - Geochimica et Cosmochimica Acta, 4, pp. 213-224.

Foster, LC., N. Allison, A.A. Finch, C. Andersson 2009: Strontium distribution in the shell of the aragonite bivalve Arctica islandica. - Geochemistry Geophysics Geosystems, 10, Q03003.

Gaffey, S.J., C.E. Bronnimann 1993: Effects of bleaching on organic and mineral phases in biogenic carbonates. - Journal of Sedimentary Research, 63, pp. 752-754.

Higuera-Ruiz, R., J. Elorza 2009: Biometric, microstructural, and high-resolution trace element studies in Crassostrea gigas of Cantabria (Bay of Biscay, Spain): Anthropogenic and seasonal influences. - Estuarine, Coastal and Shelf Science, 82, pp. 201-213.

Hurrell, J.W. 1995: Decadal trends in the North Atlantic Oscillation: Regional temperatures and precipitation. - Science, 269, pp. 676-679.

Konecsny, K. 2003: Detectable signs of climate change in the climatic and hydrologic time series of the Upper Tisza region (Az éghajlatváltozás kimutatható jelei a Felső-Tisza mentén éghajlati és hidrológiai idősorokban). Unpublished internet communication, pp. 1-20.

Shirai, K., N. Takahata, H. Yamamoto, T. Omata, T. Sasaki, Y. Sano 2008: Novel analytical approach to bivalve shell biogeochemistry: a case study of hydrothermal mussel shell. - Geochemical Journal, 43, pp. 413-420.

Lajter, I., L.J. Szabó, M. Miskolczi, Z. Lucza, Gy. Dévai 2010: Ecologic evaluation of the long term temperature change of River Tisza (A Tisza hosszú távú hômérsékletváltozásainak ökológiai szempontú elemzése). Hungarian Hydrological Society (Magyar Hidrológiai Társaság) meeting (XXVIII. ORSZÁGOS VÁNDORGYÚLÉS), Sopron. Unpublished internet communication, pp. $1-7$.

Lazareth, C.E., E. Vander Putten, L. André, F. Dehairs 2003: High-resolution trace element profiles in shells of the mangrove bivalve Isognomon ephippium: a record of environmental spatiotemporal variations? - Estuarine, Coastal and Shelf Science, 57, pp. 1103-1114.

Magyari, E.K., K. Buczkó, G. Jakab, M. Braun, Z. Pál, D. Karátson, I. Papp 2009: Palaeolimnology of the last crater lake in the Eastern Carpathian Mountains: a multiproxy study of Holocene hydrological changes. - Hydrobiologia, 631, pp. 29-63.

Magyari, E.K., A. Demény, K. Buczkó, Z. Kern, T. Vennemann, I. Fórizs, I. Vincze, M. Braun, J.I. Kovács, B. Udvardi, D. Veres 2012: A 13,600-year diatom oxygen isotope record from the South Carpathians (Romania): Reflection of winter conditions and possible links with North Atlantic circulation changes. - Quaternary International (in press)

Molnár, M., L. Rinyu, R. Janovics, I. Major, M. Veres 2012: Az új debreceni C-14 AMS Laboratórium bemutatása (Introduction of the new AMS C-14 Laboratory in Debrecen). - Archeometriai Műhely, IX/3, pp. 147-160. 
Rinyu, L., M. Molnár, I. Major, T. Nagy, M. Veres, Á. Kimák, L. Wacker, H.A. Synal 2013: Optimization of sealed tube graphitization method for environmental C-14 studies using MICADAS. - Nuclear Instruments and Methods in Physics Research Section B: Beam Interactions with Materials and Atoms, 294, pp. 270-275.

Schöll-Barna, G., A. Demény, G. Serlegi, Sz. Fábián, P. Sümegi, F. Fórizs, B. Bajnóczi 2012: Climatic variability in the Late Copper Age: Stable isotope fluctuation of prehistoric Unio pictorum (Unionidae) shells from Lake Balaton (Hungary). - Journal of Paleolimnology, 47, pp. 87-100.

Schöne, B. R., J. Fiebig 2009: Seasonality in the North Sea during the Allerod and Late Medieval Climate Optimum using bivalve sclerochronology. - International Journal of Earth Sciences (Geologische Rundschau), 98, pp. 83-98.

Shirai, K., N. Takahata, H. Yamamoto, T. Omata, T. Sasaki, Y. Sano 2008: Novel analytical approach to bivalve shell biogeochemistry: A case study of hydrothermal mussel shell. - Geochemical Journal, 42, pp. 413-420.

Spötl, C., T.W. Vennemann 2003: Continuous-flow isotope ratio mass spectrometric analysis of carbonate minerals. - Rapid Communications in Mass Spectrometry, 17, pp. 1004-1006.

Sümegi, P. 2004: Findings of geoarchaeological and environmental historical investigations at the Körös site of Tiszapüspöki-Karancspart Háromság. - Antaeus, 27, pp. 307-341.

Sümegi, P. 2007: Late Quaternary environmental history of Hungary (Magyarország negyedidőszak végi környezettörténete). - DSc Thesis, Hungarian Academy of Sciences, Budapest, p. 428. (In Hungarian.)

Synal, H.A., M. Stocker, M. Suter 2007: MICADAS: A new compact radiocarbon AMS system. Nuclear Instruments and Methods in Physics Research B, 259, pp. 7-13.

Takesue, R.K., C.R. Bacon, J.K. Thompson 2008: Influences of organic matter and calcification rate on trace elements in aragonitic estuarine bivalve shells. - Geochimica et Cosmochimica Acta, 72, pp. 5431-5445.

Tevesz, M.J.S., A.L. Spongberg, J.A. Fuller 1998: Stable carbon and oxygen isotope record of Central Lake Erie sediments. - Journal of Paleolimnology, 20, pp. 295-305.

Vander Putten, E., F. Dehairs, E. Keppens, W. Baeyens 2000: High resolution distribution of trace elements in the calcite shell layer of modern Mytilus edulis: Environmental and biological controls. - Geochimica et Cosmochimica Acta, 64, pp. 997-1011.

Vekemans, B., K. Janssens, L. Vincze, F. Adams, P. Van Espen 1994: Analysis of X-ray spectra by iterative least squares (AXIL): new developments. - X-Ray Spectrometry, 23, pp. 278-285.

Verdegaal, S., S.R. Troelstra, C.J. Beets, H.B. Vonhof 2005: Stable isotopic records in unionid shells as a paleoenvironmental tool. - Netherlands Journal of Geosciences, 84, pp. 403-408.

Versteegh, E., S.R. Troelstra, H.B. Vonhof, D. Kroon 2009: Oxygen isotope composition of bivalve seasonal growth increments and ambient water in the rivers Rhine and Meuse. - Palaios, 24, pp. 497-504.

Versteegh, E.A.A., H.B. Vonhof, S.R. Troelstra, D. Kroon 2010a: A molluscan perspective on hydrological cycle dynamics in northwestern Europe. - Netherlands Journal of Geosciences, 89, pp. 49-58.

Versteegh, E.A.A., H.B. Vonhof, S.R. Troelstra, R.J.G. Kaandorp, D. Kroon 2010b: Seasonally resolved growth of freshwater bivalves determined by oxygen and carbon isotope shell chemistry. Geochemistry, Geophysics, Geosystems, 11, pp. 1-16.

Versteegh, E.A.A., H.B. Vonhof, S.R. Troelstra, D. Kroon 2011: Can shells of freshwater mussels (Unionidae) be used to estimate low summer discharge of rivers and associated droughts? International Journal of Earth Sciences, 100, pp. 1423-1432.

Vollweiler, N., D. Scholz, C. Mühlinghaus, A. Mangini, C. Spötl 2006: A precisely dated climate record for the last $9 \mathrm{kyr}$ from three high alpine stalagmites, Spannagel Cave, Austria. - Geophysical Research Letters, 33, L20703.

Wurster, C.M., W.P. Patterson 2001: Seasonal variation in stable oxygen and carbon isotope values recovered from modern lacustrine freshwater mollusk: Paleoclimatological implications for subweekly temperature records. - Journal of Paleolimnology, 26, pp. 205-218. 